\title{
Indoor Ozone Pollution and the Purification Technologies
}

\author{
Xiaobing $\operatorname{Tian}^{1}$ \\ ${ }^{1}$ College of Resources and Environmental Engineering, \\ Wuhan University of Technology, \\ Wuhan, China
}

\author{
Zhongqin $\mathrm{Yi}^{2}$, Taosheng $\mathrm{Jin}^{2}$, Xiuyan Wang ${ }^{2}$ \\ ${ }^{2}$ College of Environmental Science and Engineering, \\ Nankai University, \\ Tianjin, China
}

\begin{abstract}
An increasing number of air pollutants, like haze, arouse people's great concern about indoor air quality. Ozone is one of key factors influencing indoor air quality. In this paper, combined recent research on indoor ozone pollution at home and abroad, the sources of indoor ozone and indoor pollution were reviewed, and some current methods and technologies of ozone purification were discussed. Based on the above presentation, more efficient and practical multiphase thermal catalysts should be developed.
\end{abstract}

Keywords-indoor air quality; ozone pollution; purification methods

Air environment is one of the important human survival environment, People living and working in the indoor environment has reached $80-90 \%$ of the time throughout the day time, especially the elderly, children and sick people, therefore, indoor air quality is directly impact on people's physical and mental health [1]. Indoor air pollutants include $\mathrm{CO}, \mathrm{NOx}, \mathrm{O}_{3}$, VOCs, etc. [2], which ozone has a strong oxidation, which can be almost any object surface reactions, indoor ozone pollution comes mainly from the outdoor environment and indoor ozone sources (such as printers, copiers, etc.) [1, 3-7]. Exposure to ozone can cause respiratory disease, injury lung function, aggravated asthma, stimulate eyes, noses, weaken the body colds, and other diseases's resistance. Accelerate the aging of lung tissue [8-14]. Meanwhile ozone can react with indoor other chemicals to produce secondary pollution, greater harm to human health. Such as terpenes react with ozone to form ultrafine particles, formaldehyde, hydrogen peroxide, carboxylic acid and other substances, and more likely to stimulate the respiratory and cardiovascular systems [15]. Currently in the indoor environment ozone pollution situation and against the current ozone purification treatment methods and techniques discussed should be further noted that the development of more efficient and practical multiphase thermal and catalytic purification technology.

\section{INDOOR AIR OZONE POLLUTION SOURCES}

The type of air pollution in China is mainly of particulate matter, sulfur coal-burning pollution, in recent years, with the car ownership increase, nitrogen oxides, and hydrocarbons as the main pollutants automobile exhaust type pollution is gradually serious, ozone is by nitrogen oxides and volatile organic compounds through a series of complex photochemical reactions important product. At high temperatures, strong sunshine, low humidity and calm wind conditions is the most violent reaction, therefore, ozone pollution problems have become increasingly prominent $[1,16]$.

Due to traffic congestion in urban areas, oxidized type air pollution problems gradually prominent, photochemical reaction is an important reaction of outdoor ozone formation. Leading to outdoor of near the ground ozone concentrations rises and forms photochemical smog, causing ozone pollution [1], with outdoor environment into the interior.

May be discharged to the indoor ozone the indoor appliances including ionizing type air purifier, negative ion generator and other air purifier equipments, copiers, laser printing equipment and other office equipment and the ozone generator and fault arc terminal devices and transformers [3-5]. U.S. EPA studies show that the incidence ozone of dry type copier is average $40 \mu \mathrm{g} / \mathrm{parts}$, up to $13140 \mu \mathrm{g} / \mathrm{copies}$, the ozone incidence of laser printer is average $43840 \mu \mathrm{g} / \mathrm{min}$. But good maintenance practices can reduce the amount of its ozone [6]; Bai Jing et al [17] found that electrostatic filter at rated wind usage may lead to indoor ozone concentration is increased $0.100 \mathrm{mg} / \mathrm{m}^{3}$. Improper use of ozone generator ozone will also be a major source of pollution of the indoor environment, to indoor and outdoor ozone conduct tracer studies have shown that outdoor ozone is the main source of indoor ozone, indoor sources to the contribution of indoor ozone is limited.

Meanwhile, the concentration of indoor ozone is affected by ventilation, temperature, humidity and pollutants in room residence time and other factors [18]. In case of no indoor source, under moderate ventilation conditions indoor ozone concentration for the outdoor concentration about $20-30 \%$; In the case of strong ventilation for about $40-70 \%$ [19].

\section{DOMESTIC AND ABROAD INDOOR OZONE STANDARD}

In recent years, as people focus on ambient air quality continues to improve, every country and every organization to indoor and outdoor air, the ozone concentration limit is also specified, as shown in Table I. 
TABLE I. INDOOR OZONE CONCENTRATION RECOMMENDED BY SOME COUNTRIES AND ORGANIZATIONS.

\begin{tabular}{|c|c|c|c|}
\hline $\begin{array}{l}\text { Countries/ } \\
\text { Organizations }\end{array}$ & $\begin{array}{l}\text { Concentration } \\
\text { Limits } \\
\left(\mathrm{mg} / \mathrm{m}^{3}\right)\end{array}$ & Duration $/ \mathrm{h}$ & Reference Source \\
\hline $\begin{array}{l}\text { China/National } \\
\text { Standard }\end{array}$ & 0.16 & 1 & $\begin{array}{l}\text { "Indoor air quality } \\
\text { standards" (GB/T18883- } \\
\text { 2002) }\end{array}$ \\
\hline $\begin{array}{l}\text { China/National } \\
\text { Standard }\end{array}$ & 0.10 & 1 & $\begin{array}{l}\text { "ozone in indoor air health } \\
\text { standards" (GB/T18202- } \\
2000)\end{array}$ \\
\hline $\begin{array}{l}\text { World Health } \\
\text { Organization } \\
\text { WHO }\end{array}$ & 0.12 & 8 & WHO(1997) \\
\hline Britain & 0.20 & 8 & $\begin{array}{l}\text { Liu Jianguo, etc.; } 2002 \\
{[20]}\end{array}$ \\
\hline Japan & 0.12 & 8 & $\begin{array}{l}\text { Liu Jianguo, etc.; } 2002 \\
{[20]}\end{array}$ \\
\hline Singapore & 0.10 & 8 & $\begin{array}{l}\text { Liu Jianguo, etc.; } 2002 \\
{[20]}\end{array}$ \\
\hline Hong Kong & 0.12 & 8 & $\begin{array}{l}\text { Liu Jianguo, etc.; } 2002 \\
{[20]}\end{array}$ \\
\hline
\end{tabular}

As can be seen from Table I of the ambient air quality standards and indoor air quality standards were significantly lower than the standard requirements of other countries and organizations. Meanwhile, China lack of the ozone long-term exposure standards, such as $8 \mathrm{~h}$ concentration limits. With the worsening environmental pollution, human health requirements should be strengthened of air quality requirements.

\section{INDOOR OZONE POLLUTION STATUS QUO AT HOME AND ABROAD}

The atmosphere near the ground in the background concentration of ozone in $0.04-0.08 \mathrm{mg} / \mathrm{m}^{3}$, average $0.06 \mathrm{mg} / \mathrm{m}^{3}$ around. Due to the presence of nitric oxide, urban areas 24 hours generally do not exceed background concentrations of ozone $0.12 \mathrm{mg} / \mathrm{m}^{3}$, indoor ozone pollution of various countries and regions are also inconsistent. Summer in North America and Germany's clean area of 7 hours daily average concentration is $0.02-$ $0.05 \mathrm{ppm}$, America's highest-hour average concentration in $0.12-0.20 \mathrm{mg} / \mathrm{m}^{3}$; In the Netherlands different urban areas 8 -hour average max value $0.20-0.35 \mathrm{mg} / \mathrm{m}^{3}$ [16]; 2008 Shanghai, the maximum daily ozone near the ground $8 \mathrm{~h}$ annual average of $88 \mu \mathrm{g} / \mathrm{m}^{3}$, which the urban is $78 \mu \mathrm{g} / \mathrm{m}^{3}$, City suburb of $96 \mu \mathrm{g} / \mathrm{m}^{3}$ [9]; 2006-2008 Suzhou City, the largest concentration of ozone 1 hour, 8-hour average concentration and maximum 24-hour average concentrations were $77.4 \mu \mathrm{g} / \mathrm{m}^{3}, 57.7 \mu \mathrm{g} / \mathrm{m}^{3}, 35.7 \mu \mathrm{g} / \mathrm{m}^{3}$ [10]. With car ownership has increased steadily worsening air pollution, ozone pollution problems will be the focus of attention.

In general, indoor and outdoor ozone concentration of ozone concentrations in the region is closely related to outdoor ozone pollution is worsening also makes indoor ozone pollution cannot be ignored [16].

BaiYuhua et al. [21] in1997 monitoring Peking University residential and public places indoor and outdoor ozone concentration, Indoor ozone between $0.006-0.12 \mathrm{mg} / \mathrm{m}^{3}$, outdoor ozone is $0.07-0.14 \mathrm{mg} / \mathrm{m}^{3}$, overall, indoor outdoor concentrations of ozone concentration equivalent to $40-80 \%$.

\section{INDOOR OZONE POLLUTION ON HUMAN HEALTH HAZARDS}

Ozone exposure (ozone exposure), that is, the concentration of ozone in this ozone concentration multiplied by the residence time, to indicate the amount of ozone applied to the human body, even under normal circumstances, indoor ozone concentration is lower than outdoor ozone concentration, However, due to the indoor time of people is almost of the total time $80-90 \%$, indoor ozone exposure is a major portion of the whole ozone exposure [16]. ozone olfactory threshold is $40 \mu \mathrm{g} / \mathrm{m}^{3}$, when the ozone concentration is less than $100 \mu \mathrm{g} / \mathrm{m}^{3}$, had no effect on measurement of concentration, when the concentration of ozone in the $200-300 \mu \mathrm{g} / \mathrm{m}^{3}$, the susceptible person eye, nose and pharynx mucosa irritation, when the ozone concentration in $300-400 \mu \mathrm{g} / \mathrm{m}^{3}$, less than 30 percent of residents in the mucous membrane irritation, $15 \%$ of residents forced expiratory volume in 1 second decline, when the ozone concentration is greater than $400 \mu \mathrm{g} / \mathrm{m}^{3}, 50 \%$ of residents have a stimulating effect, and $25 \%$ of the population will one second biggest decline in respiratory gas [22].

At the study of the relationship between ozone shortterm exposure and the risk of death in 95 urban communities of United States.

Bell et al. [23] use a variety of concentration measurement. The results showed that the concentration of each additional day $5.1 \mu \mathrm{g} / \mathrm{m}^{3}(10 \mathrm{ppb}), 8 \mathrm{~h}$ daily concentrations for each additional $7.65 \mu \mathrm{g} / \mathrm{m}^{3}(15 \mathrm{ppb})$ and $1 \mathrm{~h}$ per day increased concentrations $10.2 \mu \mathrm{g} / \mathrm{m}^{3}$ (20ppb), Population the risk of death increased respectively by $0.52 \% \quad(95 \% \mathrm{Cl}: 0.27-0.77 \%), 0.64 \%(95 \% \mathrm{Cl}: 0.41-$ $0.86 \%), 0.67 \% \quad(95 \% \mathrm{Cl}: 0.42-0.92 \%)$. Charles J. Weschler et al. [24] survey America California 600 households, the result showed indoor ozone exposure 1.25 times greater than outdoor. U.S. EPA survey LA 45 households Inhabitation, the indoor ozone concentration was $38 \%$ outdoor. Indoor ozone exposure is calculated exposure 1.7 times greater than the outside, a combination of factors, indoor ozone exposure can easily reach the outdoor ozone exposure 3-4 times, the indoor environment of ozone on human health hazards cannot be ignored.

\section{OZONE PURIFICATION METHODS AND TECHNIQUES}

The ozone which is being in the upper atmosphere is beneficial substances, but when near the ground, ozone's strong oxidizing will produce great harm, for humans and environment It is not only to the human respiratory system and other organisms have a greater harm, but also an important component of urban photochemical smog. The ozone action of threshold concentration that can cause the changes of body's sensitivity to physiological 
and biochemical index and people symptoms index is about $0.10-0.14 \mathrm{mg} / \mathrm{m}^{3}$. When indoor environment ozone concentration is $0.2 \mathrm{mg} / \mathrm{m}^{3}$ above, it will cause harm to humans [25]. So treating ozone, to decompose into harmless substances is very important. The current ozone purification methods include atmospheric ozone purification dilution method, activated carbon adsorption method, catalytic thermal decomposition method, photocatalytic decomposition method [26-30], as shown in Table II.

TABLE II. CURRENT METHODS OF OZONE PURIFICATION.

\begin{tabular}{|l|l|l|l|}
\hline $\begin{array}{l}\text { Technical } \\
\text { Methods }\end{array}$ & $\begin{array}{l}\text { Atmospheric } \\
\text { Dilution }\end{array}$ & $\begin{array}{l}\text { Activated } \\
\text { Carbon } \\
\text { Adsorption }\end{array}$ & $\begin{array}{l}\text { Catalytic } \\
\text { Decomposition }\end{array}$ \\
\hline Principle & $\begin{array}{l}\text { Introduction } \\
\text { of outside air } \\
\text { through the } \\
\text { ventilation } \\
\text { equipment }\end{array}$ & $\begin{array}{l}\text { Activated } \\
\text { carbon } \\
\text { adsorption }\end{array}$ & $\begin{array}{l}\text { Catalytic } \\
\text { decomposition } \\
\text { of ozone }\end{array}$ \\
\hline Feature & $\begin{array}{l}\text { Lower } \\
\text { equipment } \\
\text { costs, but if } \\
\text { the outside } \\
\text { air is } \\
\text { contaminated } \\
\text { indoor air } \\
\text { environment } \\
\text { will produce } \\
\text { more serious } \\
\text { consequences } \\
\text { of pollution }\end{array}$ & $\begin{array}{l}\text { Simple and } \\
\text { convenient, } \\
\text { but it is } \\
\text { easy to lose } \\
\text { activity of } \\
\text { activated } \\
\text { carbon, } \\
\text { require } \\
\text { frequent } \\
\text { replacement } \\
\text { or } \\
\text { regeneration }\end{array}$ & $\begin{array}{l}\text { High } \\
\text { recomposition } \\
\text { stability, but } \\
\text { higher costs }\end{array}$ \\
\hline
\end{tabular}

Study of ozone purification are more concentrated in multiphase heated catalysis, relatively few studies of ozone in the photocatalytic elimination, The main catalyst is a manganese-containing catalysts (e.g., $\mathrm{MnO}_{2}$, $\mathrm{MnCO}_{3}$,ozone decomposition catalyst), the catalyst containing a transition metal oxide (iron oxide, cobalt oxide, nickel oxide and the like), a catalyst containing a noble metal (Pt, $\mathrm{Pd}, \mathrm{Rh}$, etc.), titanium-containing catalyst (titanium silicon oxide, titanium manganese oxides, titanium silver manganese oxides, titanium zirconium oxide, platinum titanium silicon oxide etc.) [27].

Ohtani et al. [31] studied the hot catalytic and photocatalytic decomposition of ozone of different $\mathrm{TIO}_{2}$ that found after irradiation, ozone decomposition rate is greatly improved and rutile $\mathrm{TiO}_{2}$ active higher than other crystalline phases. For the semiconductor photocatalyst, metal particles deposited on the surface of the semiconductor light absorption efficiency and the efficiency of the photocatalytic semiconductor can be improved. Liu Dechen et al. [32] took single and double transition metal oxide supported on granular activated carbon, the result show that double metal oxide catalysts, and have a better effect for ozone decomposition.

\section{CONCLUSION AND PROSPECT}

(i) The standard of China indoor air quality significantly lower than the standard requirements of other countries and organizations, simultaneously lack of ozone long-term exposure standards (e.g., $8 \mathrm{~h}$ concentration limits), with the growing problem of indoor ozone pollution, in order to improve ambient air quality of people's lives standard limits should be promptly revised, providing technical guide for indoor air pollution control.

(ii) Study of ozone purification are more concentrated in multiphase heat catalysis. The catalyst used comprises manganese catalyst, transition metal oxide containing catalysts, noble metal-containing catalysts, titaniumcontaining catalyst etc., most are staying in the laboratory research stage. Production applications into the market there are still some difficulties. Therefore, that further research into more efficient purification technology, utility and economy to solve the problem of indoor ozone pollution is indeed.

\section{REFERENCES}

[1] Li Yanju, Study on the Changing Laws of Indoor Ozone Concentration [D]. College of Environmental Science and Engineering, Tianjin University, Tianjin, 2005.

[2] J. Zhang, Kirk R Smith. Indoor air pollution: a global health concern [J]. British Medical Bulletin, 68, pp. 209-225, 2003.

[3] D.J. Sutton, K.M. Nodolf, K.K. Makino, Predicting ozone concentrations in residential structures [J]. Ashrae Journal, 18, pp. 21-26, 1976.

[4] J.L. Niu, T.C.W. Tung, J. Burnett, Quantification of dust removal and ozone emission of ionizer air-cleaners by chamber testing [J]. Journal of Electrostatics, 51-52, pp. 20-24, 2001.

[5] Linmao Liu, Jingfu Guo, Jie Li, et al., The effect of wire heating and configuration on ozone emission in a negative ion generator $[\mathrm{J}]$. Journal of Electrostatics, 48, pp. 81-91, 2000.

[6] S.C. Lee, Sanches Lam, Ho Kin Fai, Characterization of VOCs, ozone, and PM10 emissions from office equipment in an environmental chamber $[\mathrm{J}]$. Building and Environment, 36, pp. 837-842, 2001.

[7] United States Environmental Protection Agency, Ozone generators that are sold as air cleaners: an assessment of effectiveness and health consequences [R]. National Service Center for Environmental publications (NSCEP), USA, 1995.

[8] Li Junling, Meng Ziqiang, Asian Journal of Ecotoxicology, 7(2), pp. 133-141, 2012.

[9] Chen Renjie, Chen Bingheng, Kan Haidong, China Environmental Science, 30(5), pp. 603-608, 2010.

[10] Yang Chunxue, Acute effects of fine particulate matter and ozone on daily mortality in China [D]. College of Public Health, Fudan University, Shanghai, 2012.

[11] Yan Meilin, Li Tiantian, Liu Xiaotu, et al., Journal of Environment and Health, 29(8), pp. 752-761, 2012.

[12] Wang Hanzhang, Jin Yinlong, Science of Travel Medicine, 7(2), pp. 29-33, 2001.

[13] Fiedler Nancy, Laumbach Robert, Kelly-McNeil Kathie, et al., Health effects of a mixture of indoor air volatile organics, their ozone oxidation products, and stress [J]. Environmental Health Perspectives, 113(11), pp. 1542-1548, 2005.

[14] N. Breysse Patrick, J. Buckley Timothy, Williams D'Ann, et al., Indoor exposures to air pollutants and allergens in the homes of asthmatic children in inner-city Baltimore [J]. Environmental Research, 98(2), pp. 167-176, 2005.

[15] T. Wainman, J. Zhang, C.J. Weschler, et al., Ozone and limonene in indoor air: a source of submicron particle exposure [J]. Environmental Health Perspectives, 108(12), pp. 1139-1145, 2000. 
[16] Wang Jiyong, Study of effects of chemical reactions initiated by ozone on indoor air quality [D]. College of Environmental Science and Engineering, Tianjin University, Tianjin, 2007.

[17] Bai Qian, The study of changes of indoor ozone concentrations and sources of indoor ozone [D]. College of Environmental Science and Engineering, Tianjin University, Tianjin, 2003.

[18] X. Fran, L. Leopold, M.H. William. Decomposition rates of ozone in living areas [J]. Environmental Science \& Technology, 7, pp. 342-346, 1973.

[19] Stephen T Holgate, et al., Air Pollution and Health [M]. Academic Press, USA, 1999.

[20] Liu Jianguo, Liu Yang, Liang Baosheng, et al., Chongqing Environmental Science, 24(3), pp. 79-82, 2002.

[21] Bai Yuhua, Chen Danhua, et al., Indoor Air Quality Survey [M]. Atomic Energy Press, Beijing, 1998.

[22] Сц оренкоГИцд, Journal of Environmental Hygiene, 6, pp. 338339, 1996.

[23] L. Bell Michelle, Mcdermott Aidan, L. Zeger Scott, et al., Ozone and short-term mortality in 95 US urban communities, 1987-2000 [J]. JAMA: The Journal of the American Medical Association, 292(19), pp. 2372-2378, 2004.
[24] Charles J. Weschler, Helen C. Shields. Indoor ozone exposures [J]. JAPCA, 39, pp. 1562-1568, 1989.

[25] He Panke, Yang Jianjun, Yang Dongmei, et al., Chinese Journal of Catalysis, 27(1), pp. 71-74, 2006.

[26] Fu Jiayuan, Feng Yijun, Zhong Bing, et al., Sichuan Environment, 20(1), pp. 35-39, 2001.

[27] Liu Changan, Sun Dezhi, Li Wei, et al., Environmental Protection Science, 5, pp. 1-3, 2003.

[28] Li Wei, Sun Dezhi, Liu Changan, et al., Journal of Harbin Institute of Technology, 36(5), pp. 624-626, 630, 2004.

[29] Zhang Jingjie, Zhang Pengyi, Zhang Bo, et al., Chinese Journal of Catalysis, 29(4), pp. 335-340, 2008.

[30] Liu Changan, Yang Dehua, Sun Dezhi, et al., Natural Science Journal of Harbin Normal University, 17(6), pp. 64-67, 2001.

[31] B. Ohtani, S.W. Zhang, S. Nishimoto, et al., Catalytic and photocatalytic decomposition of ozone at room temperature over titanium(IV) oxide [J]. Journal of the Chemical Society, Faraday Transactions, 88(7), pp. 1049-1053, 1992.

[32] Liu Dechen, Guo Qinghua, An Lidun, Environmental Pollution \& Control, 27(2), pp. 96-98, 2005. 